Article

\title{
Validation of a Locally Revised Topographic Index in Central New Jersey, USA
}

\section{Zeyuan Qiu}

Department of Chemistry and Environmental Science, New Jersey Institute of Technology, Newark, NJ 07102, USA; E-Mail: zeyuan.qiu@njit.edu; Tel.: +1-973-596-5357; Fax: +1-973-596-3586

Academic Editor: Miklas Scholz

Received: 19 August 2015 / Accepted: 12 November 2015 / Published: 18 November 2015

\begin{abstract}
Saturation excess is a major runoff process in humid regions such as the US Northeast. Topographic index (TI) is used to simulate the pattern of runoff-contributing areas following a saturation excess runoff process. Although TI is useful to delineate saturated areas, i.e., hydrologically sensitive areas, for taking spatially distinctive actions in watersheds for improving water quality, local resource management practitioners often question its applicability to local conditions. This study introduces two methods to validate a locally revised TI in humid central New Jersey, USA. The revised TI uses soil moisture deficit instead of water table depth as the state variable in simulating the saturation excess runoff process. First, the calculated TI values were compared to the soil moisture measurements sampled in two sites in Tewksbury Township in the region to evaluate their correlations. Second, a watershed model Variable Source Load Function (VSLF) that incorporates TI was applied to the Neshanic River Watershed in the region and compared to another watershed model Soil and Water Assessment Tool (SWAT) to evaluate its capability in predicting the streamflow and its runoff and baseflow components. The positive correlations between soil moisture measurements and TI suggested TI is a good indicator of runoff-generating potential. VSLF achieves a modeling efficiency comparable to SWAT in simulating watershed hydrology. Such validation gives practitioners confidence to incorporate TI pattern into watershed management practices for improving their efficiency. The results are applicable to shallow, interflow-driven watersheds in humid regions.
\end{abstract}


Keywords: variable source area hydrology; topographic Index; soil moisture; Variable Source Load Function (VLSF) Model; Soil and Water Assessment Tool; Neshanic River watershed

\section{Introduction}

Saturation excess is a major runoff process in humid regions such as the US Northeast and can be better captured by a physical hydrology concept called Variable Source Area (VSA) hydrology [1-3]. The VSA hydrology applies a saturation-excess hydrological process to explain that runoff-carrying pollutants contribute to the stream hydrograph are primarily generated in relatively small but predictable hydrologically sensitive areas in a watershed where soils are saturated [4-6]. The VSA hydrology presents interesting insights regarding the complex hydrological connections between streams and their upland contributing areas and offers practical guidance on managing the upland contributing areas to achieve desired water quality in streams. The VSA hydrology has been closely linked to the delineation and management of critical source areas (CSAs) for achieving long-term water quality goals and the sustainability of managing water resources more efficiently and effectively [7-13].

The topographic index (TI) was first introduced as a basis for a rainfall-runoff model, the TOPography-based hydrological MODEL (TOPMODEL), which simulates the pattern of surface runoff-contributing areas following the VSA hydrology [13]. The index measures the propensity of a given point in a watershed to become saturated and act as a source area for surface runoff [14]. The index is often called a wetness index and is used to predict soil moisture distribution in the landscape $[15,16]$. Because of its simplicity and ability to visualize the spatial predictions, TI has been widely adopted to simulate hydrologic processes with various modifications and extensions that reflect different modeling assumptions and take account of additional natural resource conditions [17-19]. TI and its variants have been incorporated into rainfall-runoff models to predict streamflow [20-23].

TI and its variants had been subject to intensive investigation on its ability to predict the spatial pattern of runoff-contributing areas in hydrology literature. The predicted spatial patterns were compared to the measured soil moisture pattern [24-26], the shallow groundwater table [27,28], and the observed wetland occurrence $[29,30]$. However, the validation results were mixed. While reasonable correlation between observed soil moisture patterns and TI was found [31,32], many found a poor correlation between predicted and observed spatial patterns, especially the point-to-point correlation [33-35]. The poor correlation was not entirely unexpected because of measurement errors and varying local resource conditions [35].

One TI variant was to re-conceptualize TI using the soil moisture deficit instead of the water table depth as the state variable to make it applicable to shallow, interflow-driven watersheds in the US Northeast [36]. The revised TI has been extensively evaluated in terms of its ability to predict the spatial pattern of runoff-contributing areas, and to predict streamflow in the New York Catskill Mountains. The patterns of runoff potential as predicted by the revised TI were compared to the field soil monitored moisture pattern and to the runoff pattern predicted by a fully distributed Soil Moisture Routing (SMR) model in the Town Brook Watershed in the same region [11,37]. SMR is a 
mechanistic physical-based, spatially distributed model that captures the VSA hydrology of humid, temperate regions such as the US Northeast that have highly permeable, sloping soils over a restricting layer [38]. They concluded the revised TI was a good indicator of runoff risk, especially in US Northeast. A normalized difference water index derived from medium resolution Landsat 7 Enhanced Thematic Mapper Plus (ETM+) images using an unsupervised classification method was used to delineate the saturated areas, and the delineated pattern of saturated areas matched the predictions made using the revised TI in the Town Brook watershed well [39]. A variable source loading function (VSLF) model was developed by incorporating the revised TI to modify the Soil Conservation Service curve number (SCS-CN) rainfall-runoff method in the popular General Watershed Loading Function (GWLF) model $[40,41]$. The VSLF model provides a much more valid spatial distribution of soil moisture and runoff generation as compared to the GWLF and other current SCS-CN-based water quality models. Consequently, using such a model could improve the simulation accuracy of pollutants transported by runoff [23].

The objective of this study is to validate this locally revised TI in central New Jersey, which is located in the humid US Northeast. Two methods were used to evaluate how well the revised TI would perform in terms of its ability to predict VSA patterns and watershed hydrology in central New Jersey. First, the soil moistures were measured using a time domain reflectometry (TDR) soil moisture meter in selected fields and the TDR measurements were compared to the TI values to evaluate their correlations. Second, the VSLF model was applied to a suburban watershed with mixed land uses located in central New Jersey and the modeling results will be compared to a distributed biophysical model called the Soil and Water Assessment Tool (SWAT), which was applied to the same watershed to evaluate its capability in predicting streamflow and its runoff and baseflow components. Located at the outskirts of the New York metropolitan area, central New Jersey has been experiencing rapid urban development as a part of suburbanization and exurbanization processes, which creates substantial stresses to natural resources. Local communities have been active in protecting their natural resources for achieving the long-term sustainability of water resources in the region. The TI validation results would help the local communities to adopt spatially targeting strategies to direct their protection efforts to CSAs and therefore achieve a greater efficiency in protection $[12,13]$.

\section{Data and Methods}

\subsection{Study Area}

The study was conducted in Hunterdon County, which is located in central New Jersey (Figure 1). Soil moisture measurement was conducted on two sites in Tewksbury Township to validate the derived TI. The Cold Brook Preserve is a 116 hectare (ha) preserved parkland managed by the Hunterdon County Parks and Recreation Division, much of which was contracted to a local farm for active cropping activities. The Christy Hoffman Farm Park is a 69 ha community park managed by Tewksbury Township for recreation. Both sites consist of gently rolling hills, have diverse topographic variation, and are easily accessible from county roads. They were selected because of those characteristics and the close contact between the research team and the public agencies that manage these sites. 
Watershed modeling was conducted in the 7897 ha Neshanic River Watershed, a suburban watershed with mixed land uses located in Hunterdon County. The watershed is comprised of $36 \%$ agriculture, $31 \%$ urban, $21 \%$ forest, and $10 \%$ wetlands, with the remaining lands both barren and in water. The climate in the region is humid with typical hot and humid summers and cold winters. The average high temperature in summer is $27-30{ }^{\circ} \mathrm{C}$ and the average low temperature in winter is -7 to $-5{ }^{\circ} \mathrm{C}$. The mean annual precipitation in the watershed is $1218 \mathrm{~mm}$. Snowfall in the winter season is $120-770 \mathrm{~mm}$, but varies yearly. Urban development and agricultural operation have degraded water quality in the Neshanic River, leading to impairment from dissolved oxygen, phosphorus, total suspended solids, and nitrogen [42]. Various best management practices were taken to improve water quality in the watershed [43].

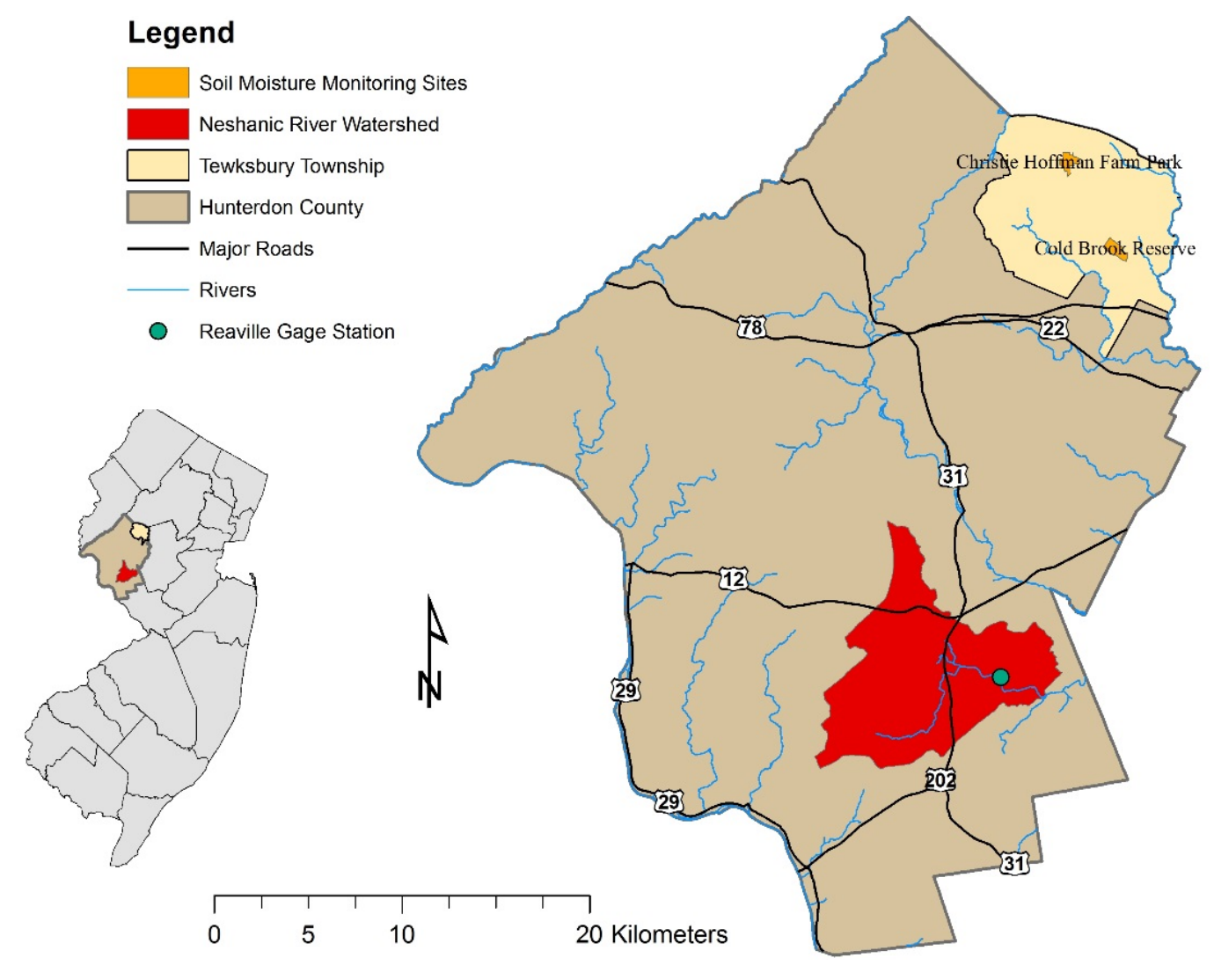

Figure 1. The location of the study sites.

\subsection{Topographic Index}

The most common form of TI $(\lambda)$ is the wetness index:

$$
\lambda=\ln \left(\frac{\alpha}{\tan (\beta)}\right),
$$

where $\alpha$ is the upslope contributing area per unit contour length in meters to a given point in a watershed and $\beta$ is the local surface slope angle in radians. The revised TI that predicts the spatial distribution of runoff-contributing areas is approximated as follows [36]:

$$
\lambda=\ln \left(\frac{\alpha}{\tan (\beta) K_{S} D}\right)=\ln \left(\frac{\alpha}{\tan (\beta)}\right)-\ln \left(K_{S} D\right),
$$


where $D$ is the local soil depth in meters to the fragipan, bedrock, or other type of restrictive layer; $K_{s}$ is the mean saturated hydraulic conductivity of the soil profile in meters per day above the restrictive layer; and the other variables are defined as before.

Equation (2) has two components: the wetness index, $\ln \left(\frac{\alpha}{\tan (\beta)}\right)$, and the soil water storage index, $\ln \left(K_{S} D\right)$. In addition to the topography, the revised TI considers the impacts of the soil water storage capacity $\left(K_{S} D\right)$ above the restrictive layer. In general, the deeper the topsoil $(D)$ and the higher the saturated hydraulic conductivity $\left(K_{s}\right)$, the lower the $\lambda$ value, which implies a lower likelihood of generating surface runoff. In reality, there may be several topsoil layers with different $K_{s}$ values above a restrictive layer or bedrock. In this case, $K_{S}$ is defined as:

$$
K_{s}=\frac{d}{\sum_{1}^{n}\left(d_{i} / k_{i}\right)}
$$

where $d$ is total thickness of the soil above the restrictive layer; $d_{i}$ is the thickness of layer $i$; $k_{i}$ is the saturated hydraulic conductivity of layer $i$ [44].

The revised TI presented in Equation (2) was derived using two spatial datasets: a $10 \mathrm{~m}$ digital elevation model (DEM) obtained from the New Jersey Department of Environmental Protection (NJDEP) and a Soil Survey Geographic (SSURGO) soil database obtained from the US Department of Agriculture Natural Resources Conservation Service. DEM was first processed using the open source ArcGIS extension Terrain Analysis Using Digital Elevation Models (TauDEM) Version 3.1 [45] and ArcGIS Raster Calculator to obtain a wetness index grid. The soil depth $(D)$ and the mean saturated hydraulic conductivity $\left(K_{S}\right)$ were extracted for each soil type from the SSURGO soil database. The product $\left(K_{S}^{*} D\right)$ for each soil type was calculated and linked to the soil spatial distribution GIS layer. The soil layer was converted into a soil water storage index raster layer based on the value of $\ln \left(K_{S} D\right)$. The converted raster layer had the same resolution as the wetness index raster layer and was also in alignment with the wetness index raster layer. The ArcGIS Raster Calculator was used to manipulate the raster layers for the wetness index derived from the DEM and the soil water storage index from the SSURGO soil data and to calculate the TI based on Equation (2).

\subsection{Soil Moisture Measurement}

The FieldScout TDR 300 soil moisture meter with a $12 \mathrm{~cm}$ rod was used to measure soil moisture at the depth of $0-12 \mathrm{~cm}$ in the Cold Brook Reserve and Christy Hoffman Farm Park. The TDR meter converts a measured electrical signal into soil moisture content using an equation that was validated over a wide range of mineral soils. The calibration is not required for general use, and is only recommended for maximum accuracy [46]. The TDR meter has two volumetric water content (VWC) modes for measuring soil moisture: one for standard soils and the other for highly clay soils. Based on the soil conditions in the fields, the mode for standard soils was used in this study and no calibration was conducted. Locations where soil moisture was measured were recorded using a Global Positioning System (GPS) system, Trimble GeoXH handheld. The GeoXH handheld provides real-time subfoot $(<30 \mathrm{~cm})$ accuracy with the internal antenna, or decimeter $(10 \mathrm{~cm} / 4$ inch $)$ accuracy after post-processing. NJDEP GPS Data Collection Standards for GIS Data Development were followed when collecting the location data [47].

The Cold Brook Reserve was visited three times on 8 June 2009, 1 December 2009, and 30 April 2010, 
respectively. Christy Hoffman Farm Park was visited two times on 1 December 2009 and 17 December 2009, respectively. Locations for taking soil moisture measurements using TDR were determined on site to ensure these locations were spread across variety of topographic changes such as flat and sloping areas. Different routes in these fields were taken for those visits. The adjacent sampling locations were roughly 10 meters apart, considering the restriction imposed by the DEM resolution. Once a location was selected, three soil moisture measurements were taken at three points around the location using the TDR meter. The three points were generally one meter apart, forming a triangle shape. The average of the three soil moisture measurements was used for further analysis. Table 1 summarizes the soil moisture measurement activities at the two sites. The recorded sampling locations and the measured soil moisture data were imported into ArcGIS for data processing and interpolation. The value of the derived TI for each sampling location was extracted from the calculated TI raster layer.

Table 1. Soil moisture measurements in two fields in Tewksbury Township.

\begin{tabular}{|c|c|c|c|c|c|c|}
\hline \multirow{2}{*}{\multicolumn{2}{|c|}{$\begin{array}{c}\text { Items } \\
\text { Sampling Location }\end{array}$}} & \multicolumn{5}{|c|}{ Sampling Site and Event } \\
\hline & & \multicolumn{3}{|c|}{ Cold Brook Farm } & \multicolumn{2}{|c|}{ Christy Hoffman Park } \\
\hline \multicolumn{2}{|c|}{ Sampling Date } & 8 June 2009 & 1 December 2009 & 30 April 2010 & 1 December2009 & 17 December 2009 \\
\hline \multicolumn{2}{|c|}{ Weather Conditions } & $\begin{array}{l}\text { Sunny, } 78^{\circ} \mathrm{F} \text {, } \\
\text { no rain in } \\
\text { past two days }\end{array}$ & $\begin{array}{l}\text { Sunny, windy, } \\
47^{\circ} \mathrm{F} ; 0.86 \mathrm{~cm} \\
\text { rain a day before }\end{array}$ & $\begin{array}{l}\text { Sunny, } 60^{\circ} \mathrm{F} ; \\
0.03 \mathrm{~cm} \text { rain } \\
\text { a day before }\end{array}$ & $\begin{array}{c}\text { Sunny, windy, } \\
47^{\circ} \mathrm{F} ; 0.86 \mathrm{~cm} \text { rain } \\
\text { a day before }\end{array}$ & $\begin{array}{l}\text { Sunny, windy, } \\
29^{\circ} \mathrm{F} \text {; no rain } \\
\text { a day before }\end{array}$ \\
\hline \multicolumn{2}{|c|}{ Sampling Points } & 146 & 138 & 140 & 111 & 158 \\
\hline \multirow{3}{*}{ TDR Reading } & Mean & 19.5 & 5.6 & 25.3 & 7.4 & 15.2 \\
\hline & Minimum & 11.6 & 2.3 & 14 & 2.9 & 2.6 \\
\hline & Maximum & 39.4 & 9.5 & 37.9 & 11.8 & 31.5 \\
\hline Corresponding & Mean & 7.5 & 7.5 & 8.1 & 7.6 & 8.3 \\
\hline Topographic & Minimum & 5.9 & 6.3 & 5.9 & 5.3 & 5.2 \\
\hline Index & Maximum & 10.4 & 9.1 & 12.4 & 12.3 & 12.0 \\
\hline
\end{tabular}

The spatial patterns of the measured soil moistures were analyzed using various interpolation techniques in the Spatial Analyst to virtually evaluate whether they match the spatial patterns of the TI values. Since the sample points were selected on site as the TDR soil moisture was measured, there was no control over the corresponding TI values of the selected locations, which resulted in a uneven distribution of sample locations corresponding to different TI values. To offset the impacts of such unevenness in data distribution, the statistical analysis of the relationship between the TDR measurements and TI values was based on binned data. The pairs of data at all sampling locations were first sorted by TI values. Based on the ranges of TI values, the data was separated into several TI value bins with incremental intervals of TI values. The number of bins and the corresponding ranges of the TI values vary by each sampling event. The average TDR measurement was calculated for all sampling locations falling within a specific bin. The regression analysis and plotting were based on the lower bound of the TI value in each bin and the corresponding average TDR measurement. 


\subsection{VSLF Modeling}

The VSLF model was applied to the 6493 ha upper portion of the Neshanic River Watershed which drains in to the U.S. Geological Survey (USGS) Reaville Gage Station at the intersection of Reaville Road and the Neshanic River as shown in Figure 2.

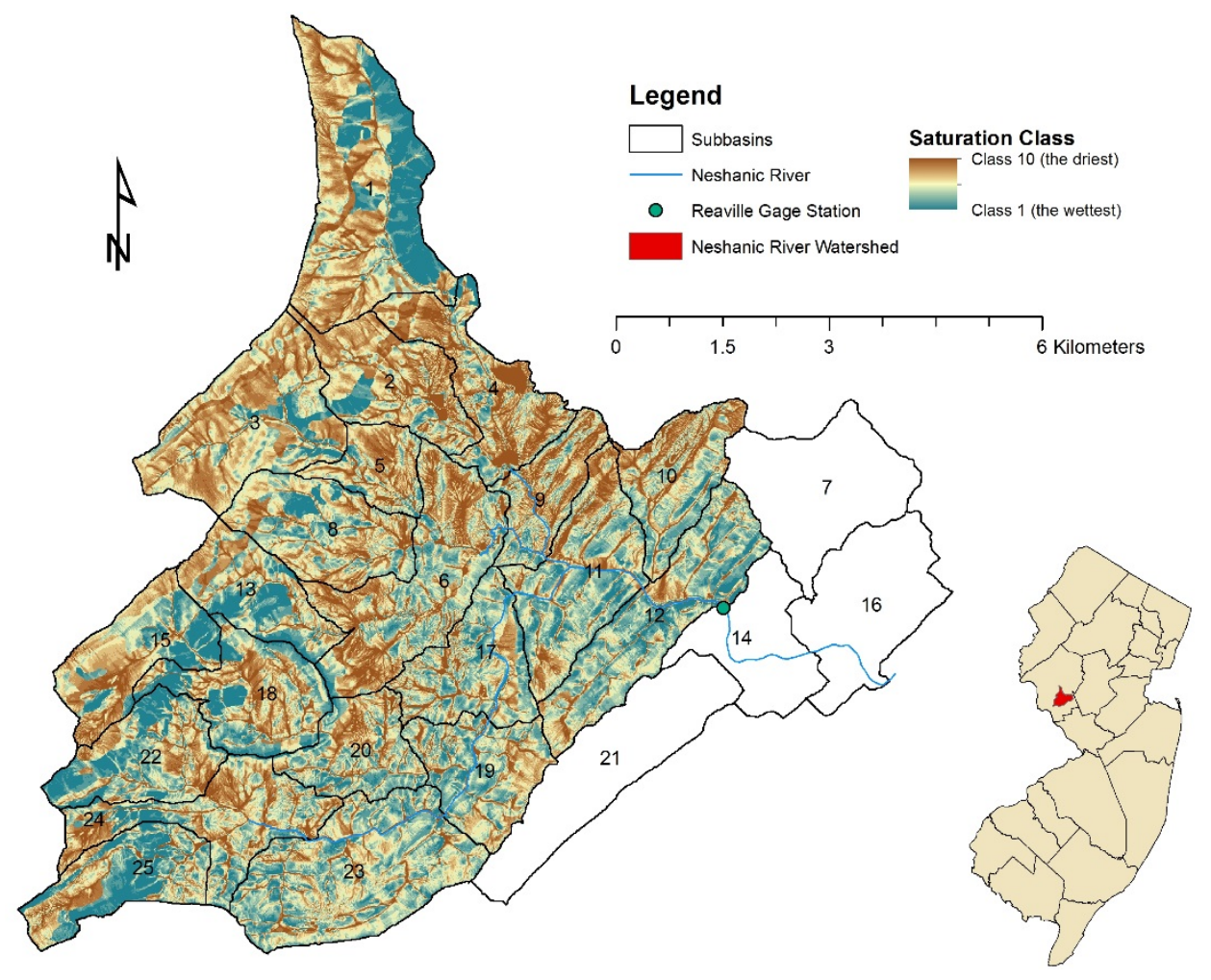

Figure 2. The spatial distribution of TI in the Neshanic River Watershed.

The standard SCS-CN method used in the GWLF model was reconceptualized to estimate the runoff from VSAs in the VSLF model [23]. The VSLF model simulates the watershed runoff response to rainfall using the standard SCS-CN method, and spatially distributes the runoff response according to a soil saturation index. While the runoff estimation from the impervious surfaces was kept the same as in GWLF, the runoff estimation in the pervious portion of the watershed was revised to capture the saturation excess runoff process. The watershed was divided into 10 saturation classes with equal areas based on the TI values, as shown in Figure 2. The watershed runoff depth $Q$ is the aerially weighted sum of runoff depths $q_{i}$ for all discrete contributing areas:

$$
Q=\sum_{i=1}^{10} q_{i} \Delta A_{s, i}
$$

where $i$ is the index of saturation class, $\Delta A_{s, i}$ is the fraction of the watershed in the saturation class $i$, and $q_{i}$ is the per unit runoff depth for saturation class $i$ predicted by the traditional SCS-CN rainfall-runoff method based on land use and soil conditions within the saturation class.

The 2002 land use/cover data developed from the aerial photographs taken in the spring of 2001 by NJDEP was overlapped with the derived saturation class layer to identify the land use distribution in each saturation class. The NJDEP land use/cover data used a modified Anderson classification system [48]. 
The land uses were classified into six broad land use categories including agriculture, barren, forest, urban, water, and wetlands, and 50 subcategories using four digital land use classification codes. The NJDEP land use/cover data contained the impervious surface rate for each land use polygon. The impervious surface rate was used to separate the total area of each land use category in each saturation class into two parts: pervious and impervious areas. The NJDEP four digital land use classification codes for the pervious areas in each saturation class were reclassified into the following land use categories required by the VSLF model: forest deciduous; coniferous forest; mixed forest; brushland; cropland and pasture; residential; commercial and industrial, roads; wetlands; and water. The impervious areas in all saturation classes were lumped into the following land use categories for the watershed: barnyard, residential impervious, commercial and industrial impervious, and roads. For example, the impervious areas from all agricultural lands and residential land uses were lumped into barnyard and residential impervious, respectively. The NJDEP land use classification did not distinguish the specific uses of agricultural lands. In the application, the total agricultural lands in each saturation class were further divided into pasture, permanent hay, and cropland based on the following percentages: $30 \%, 20 \%$, and $50 \%$, respectively. Those percentages were based on the field observation data obtained through two rounds of agricultural land use inventories throughout the watershed during the period 2007-2008.

The precipitation, maximum and minimum temperature during 1960-2008, solar radiation, and relative humidity during 1960-2008 in the Flemington weather station, which was just outside of the watershed, were collected for the modeling. Daily streamflow was obtained from the Reaville Gage Station, observed over the years 1960-2008, and was compiled and used as a model input.

The VSLF model was calibrated for the period 1997-2002. A 20-step program to calibrate each of the calibration parameters was used to calibrate the model. In each step the value of a parameter was adjusted until an optimization goal was reached. The optimization goal is either to minimize the bias (absolute value of difference between mean observed and mean simulated), or to maximize the Nash-Sutcliffe efficiency (NSE) [49] in comparing the simulated to the observed output variable affected. The calibrated model was then used to validate its capacity to simulate the streamflow during the period 2003-2008. To calibrate and validate the VSLF model, the observed and VSLF-simulated streamflow was further separated into two components: surface runoff and baseflow. Specifically, runoff was calculated by the baseflow separation method using beta $=0.925$ [50]. Eventswitch divides the time series into successive storm event periods using a minimum hydrograph rise threshold of $0.001 \mathrm{~cm}$ [4]. The eventswitch time series was used in the model for defining events. The means and standard deviations of the VSLF-simulated streamflow and its two components were compared to the observed values. The goodness of fit, i.e., agreement between simulated and observed values, was assessed using NSE on the $[-\infty, 1]$ interval. The closer the coefficient is to 1 , the better the fit.

\subsection{SWAT Modeling}

A similar watershed modeling effort was conducted in the Neshanic River Watershed using SWAT. SWAT is one of many distributed watershed models that has been widely used to understand the hydrological cycle and processes, simulate the hydrological and water quality impacts of land use and management practices, and evaluate alternative management strategies to improve water quality and 
ecosystem functions in watersheds [51,52]. Unlike the VSLF model that distinguishes a watershed into 10 saturation classes to evaluate its hydrological responses under different types of land uses, SWAT delineates a watershed into smaller subbasins based on hydrological connections and further into hydrological response units (HRUs) base on land use, topography, and soil conditions [53,54]. HRUs are unique combinations of land use, soil, and slope, which allow the model to reflect differences in evapotranspiration and other hydrologic conditions across subbasins and the watershed.

Based on DEM and the stream network, the watershed was delineated into 25 subbasins as shown in Figure 2. The outlet of Subbasin 12 coincides with the Reaville Gage Station. Similar to the VSLF modeling, the land use for the SWAT model was based on the 2002 NJDEP land use/cover data and the detailed land use activities in the watershed obtained by two rounds of agricultural land use inventories throughout the watershed during the period 2007-2008. The area percentage thresholds for defining HRUs were set at $1 \%, 20 \%$, and $25 \%$ for land use, soil, and slope, respectively. As such, 625 individual HRUs were defined for the 25 subbasins delineated in the watershed. The drainage area of the Reaville Gage Station (i.e., the outlet of Subbasin 12) contains 21 subbasins and 523 HRUs. Similarly, the precipitation, maximum and minimum temperature during 1960-2008, solar radiation, and relative humidity during 1960-2008 in the Flemington weather station were used for the SWAT modeling.

The streamflow observed at the Reaville Gage Station during 1960-2008 was similarly processed into surface runoff and baseflow as discussed before to calibrate and validate the SWAT model. NSE was used to evaluate the goodness of fit between the SWAT-simulated and the observed streamflow and their two components. The SWAT model was calibrated for the period 1997-2002 and validated for the period 2003-2008 to be compared to the VSLF model.

\section{Results}

\subsection{Comparison between DTR Measurements and TI Values}

The interpolated soil moisture and the predicted TI patterns did not show good correlation, which further confirmed the difficulty of point-to-point comparison [35]. Site-specific soil moisture is affected by many different factors such as vegetation, small variations in topography, and soil compact. The statistical approach based on binned data was used to eliminate the impacts of site-specific factors to assess the relationship between TI and TDR measurements.

Figure 3 presents the soil moisture sampling locations and the relationship between TDR measurements versus TI values at Cold Brook Farm during three field visits on 8 June 2009, 1 December 2009, and 30 April 2010. Three graphs showed a positive relationship between TDR measurements and TI values, i.e., a higher TI value corresponded to a higher TDR measurement. The relationship was especially strong when the sampling took place across a larger variation of topographic change indicated by a wider range of TI values and a wetter condition indicated by higher TDR measurements. The $R^{2}$ values were 0.94 and 0.88 on 8 June 2009 and 30 April 2010, respectively. On the other hand, the $\mathrm{R}^{2}$ value was only 0.45 despite a positive relationship between the TDR measurement and TI value on 1 December 2009 when the sampling took place in a gradient with a small topographic variation in a dry weather condition. 

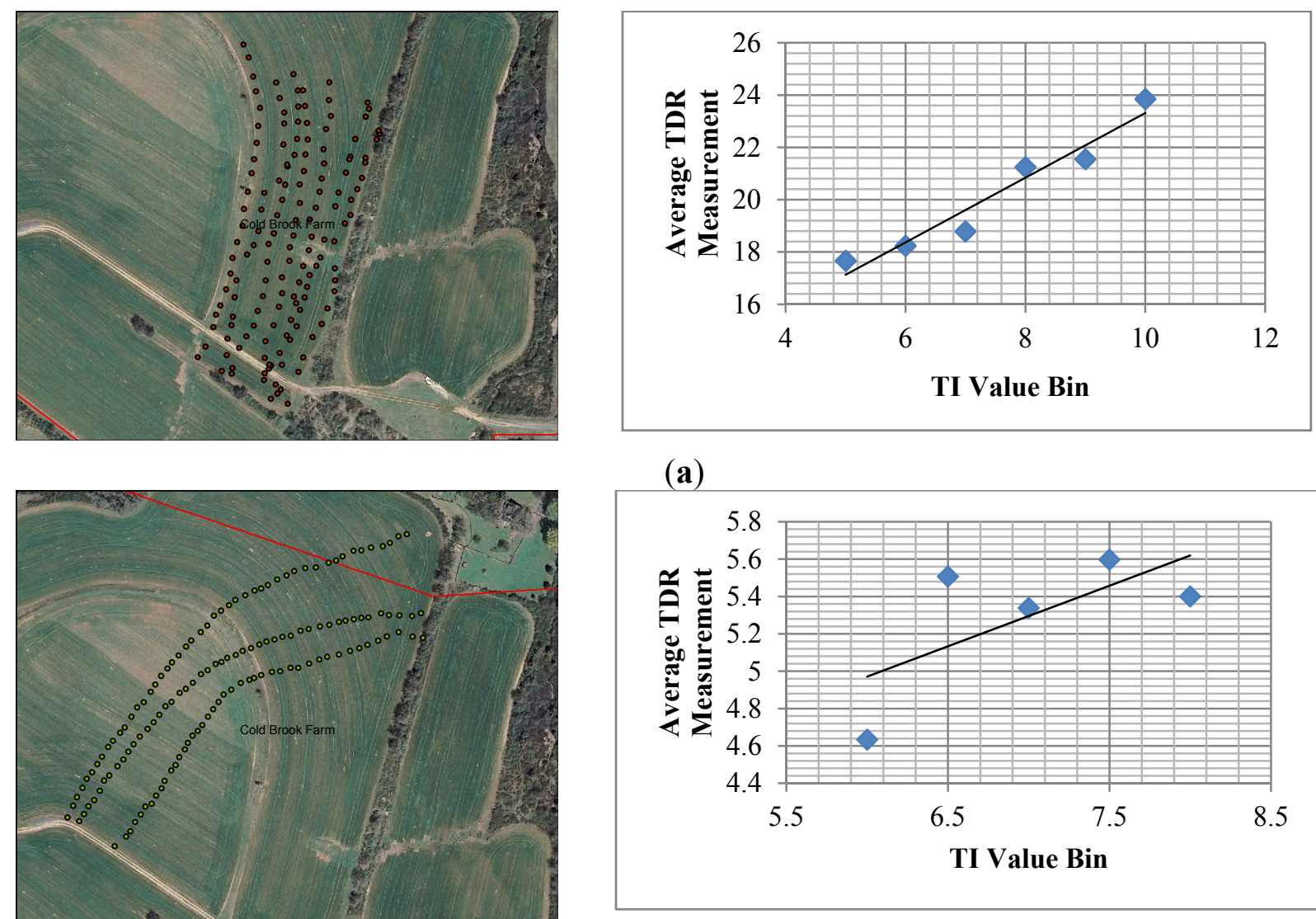

(a)

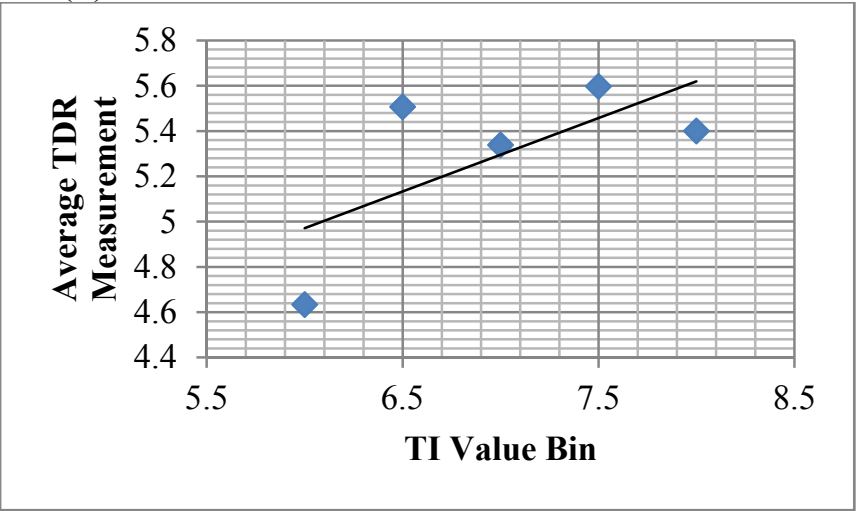

(b)
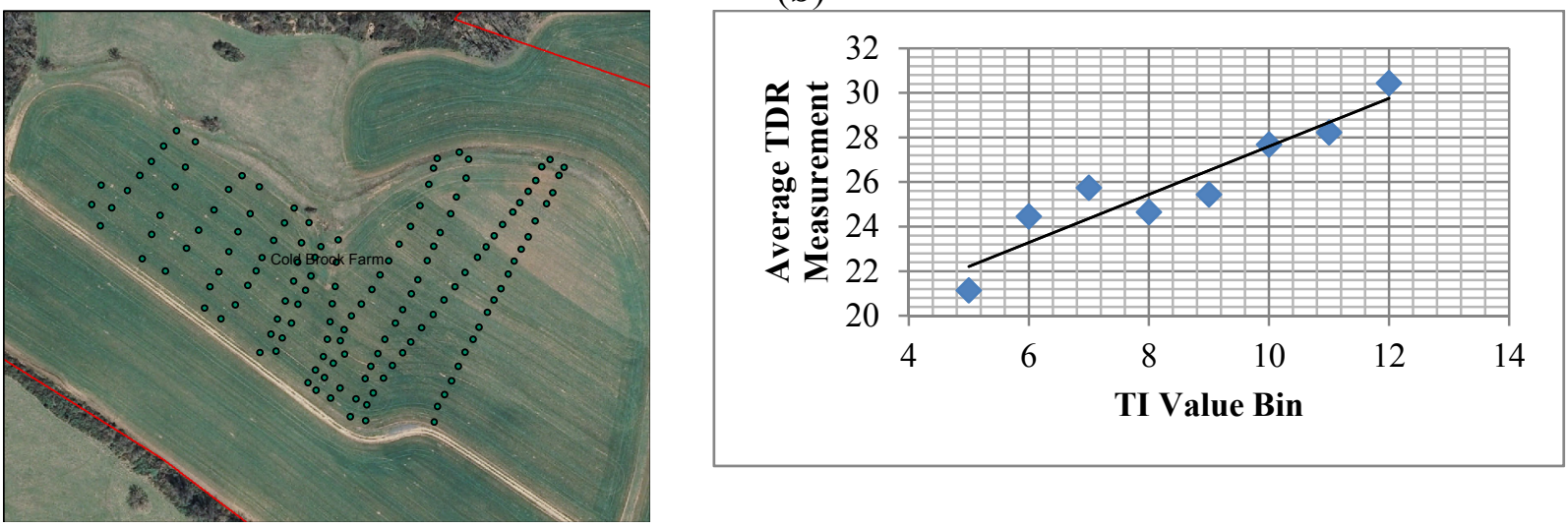

(c)

Figure 3. Comparison between TI Values and TDR Measurement (\%) at Cold Brook Farm. (a) On 8 June 2009 (TDR $\left.=1.2373 \mathrm{TI}+10.942 ; R^{2}=0.9402\right)$; (b) On 1 December 2009 $\left(\mathrm{TDR}=0.3246 \mathrm{TI}+3.0231 ; R^{2}=0.4489\right) ;(\mathbf{c})$ On 30 April $2010(\mathrm{TDR}=1.0783 \mathrm{TI}+16.813$; $\left.R^{2}=0.8764\right)$.

At Christy Hoffman Farm Park, as shown in Figure 4, the TDR measurements were also perfectly and positively correlated with the TI values with $R^{2}=0.96$ on 17 December 2009, but the data on 1 December 2009 showed a positive but very weak correlation between the TDR measurements and the TI values with $R^{2}=0.07$. The different results were due to the weather conditions around the sampling dates. On 1 December 2009, the ground was very dry as indicated by low TDR measurements with very little variation, while on 17 December 2009, the soils were saturated as indicated by the wide range of TDR measurements. 

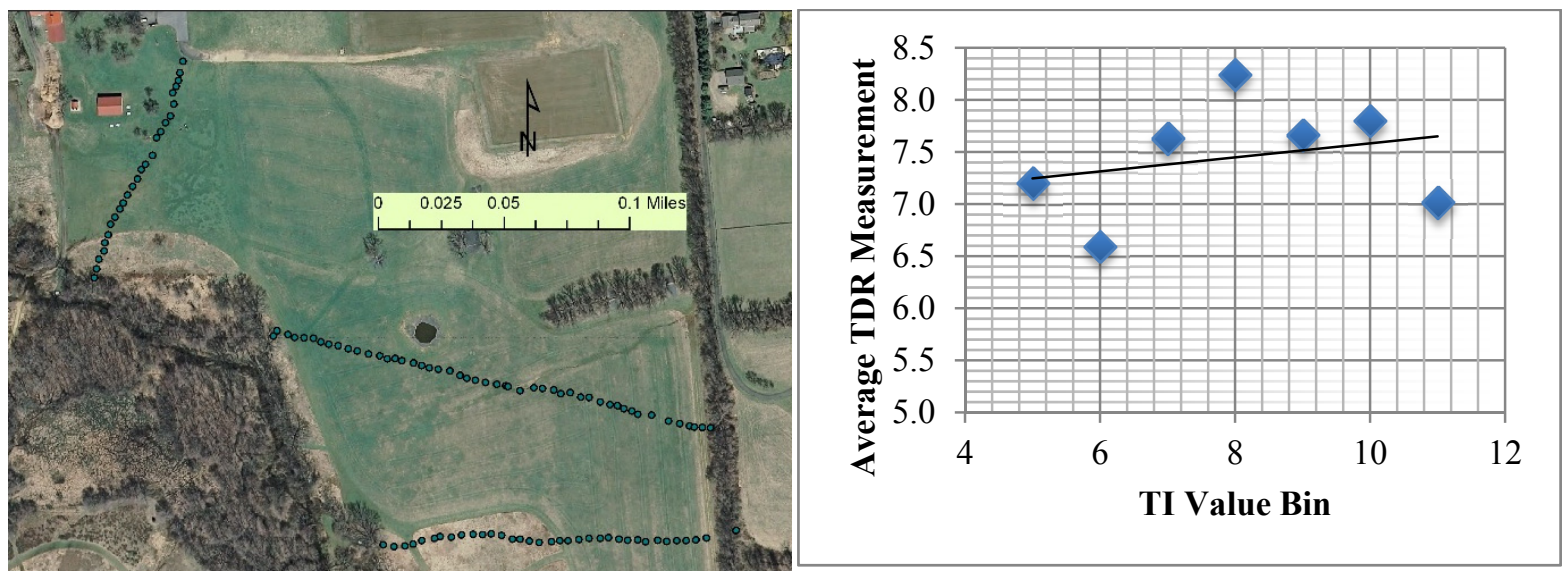

(a)
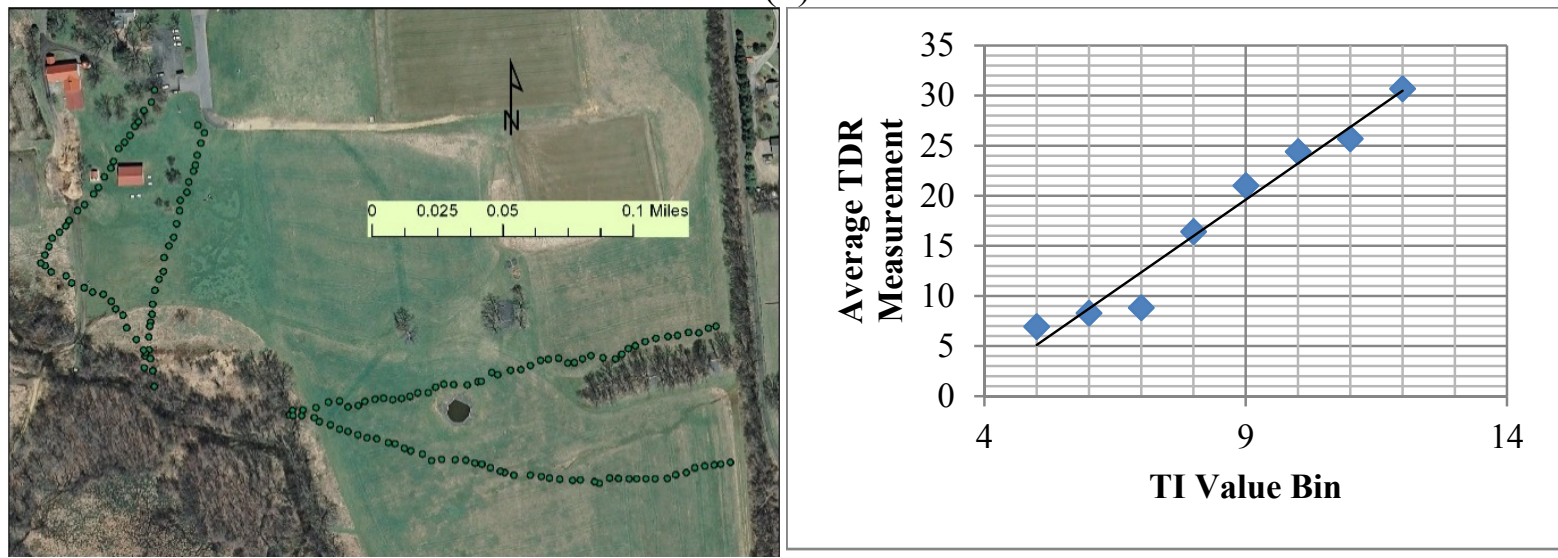

(b)

Figure 4. Comparison between TI Values and TDR Measurement (\%) at Christy Hoffman Farm Park. (a) On 1 December 2009 (TDR $=0.0674 \mathrm{TI}+6.9094 ; R^{2}=0.0703$ ); (b) On 17 December 2009 (TDR $\left.=3.6251 \mathrm{TI}-13.014 ; R^{2}=0.9633\right)$.

\subsection{Comparison between VSLF and SWAT}

Table 2 presents the seven VSLF calibration parameters, their affected hydrological variables, optimization goals being used, default values, original values calibrated by the model developer for a watershed in New York, and calibrated values from the Neshanic River Watershed. The calibrated values of the precipitation correction, SMIN and SMAX factors, were close to the original values. The calibrated values for the precipitation correction factor, runoff recess co-efficient, recess coefficient, and bypass coefficient were close to the default values. The only exception was the melt factor that determines the rate of snowpack melting. The calibrated value of 0.99 was much larger than the default value of 0.45 and the original value of 0.41 for the New York watershed. The difference in the melt factor value suggested the quite different snowpack melting processes among those watersheds due to their geographic location. The Neshanic River Watershed is located in the south of the New York watershed and much closer to the Atlantic Coast, and therefore snowpack melting would take place much faster. The SWAT calibration process and parameters were found in [55]. 
Table 2. The default, original, and calibrated values for seven calibration parameters for the Variable Source Loading Function (VSLF) model.

\begin{tabular}{cccccc}
\hline $\begin{array}{c}\text { Hydrology Calibration } \\
\text { Parameter }\end{array}$ & $\begin{array}{c}\text { Affected Output } \\
\text { Variable }\end{array}$ & $\begin{array}{c}\text { Optimization } \\
\text { Goal }\end{array}$ & $\begin{array}{c}\text { Default } \\
\text { Value }\end{array}$ & $\begin{array}{c}\text { Original } \\
\text { Value }\end{array}$ & $\begin{array}{c}\text { Calibrated } \\
\text { Value }\end{array}$ \\
\hline Precip. Correction Factor & Stream flow & Minimize bias & 1 & 0.951625 & 0.950230 \\
SMIN Factor & Runoff per [day dormant] & Minimize bias & 0.434783 & 0.170942 & 0.183991 \\
SMAX Factor & Runoff per [day growing] & Minimize bias & 2.380950 & 1.343430 & 1.190920 \\
Runoff Recess Coefficient & Runoff & Maximize NSE & 1 & 0.412917 & 0.901439 \\
Melt Factor & Stream flow & Maximize NSE & 0.45 & 0.409741 & 0.992740 \\
Recess Coefficient & Base flow & Maximize NSE & 0.1 & 0.061885 & 0.095339 \\
Bypass Coefficient & Stream flow (lowflow) & Minimize bias & 0 & 0.059946 & 0.028769 \\
\hline
\end{tabular}

The comparison between the SWAT- and VSLF-simulated and the observed daily, monthly, and annual runoff, baseflow, and streamflow at the USGS Reaville Gage Station during the calibration period 1997-2002 is presented in Table 3. The NSEs for the calibrated SWAT model were 0.58, 0.37, and 0.57 for the daily surface runoff, baseflow, and streamflow; $0.65,0.61$, and 0.68 for the monthly surface runoff, baseflow, and streamflow; and $0.48,-1.95$, and 0.40 for the annual surface runoff, baseflow, and streamflow during the calibration period, respectively. The NSEs of the calibrated VSLF model were $0.54,0.55$, and 0.54 for the daily surface runoff, baseflow, and streamflow; $0.68,0.75$, and 0.74 for the monthly surface runoff, baseflow, and streamflow; and $0.85,0.64$, and 0.86 for the annual surface runoff, baseflow, and streamflow during the calibration period, respectively. For a monthly time step, the model performance is considered to be good for NSE values that fall in the range between 0.65 and 0.75 and to be very good for values between 0.75 and 1 [56]. The reported NSE values of 0.68 and 0.74 for monthly streamflow indicated that both SWAT and VSLF models were well calibrated in the watershed. SWAT was better calibrated for daily streamflow while VSLF was better for monthly and annual streamflow. Both models underestimated the variability of streamflow as evidenced by the smaller standard deviations for the simulated streamflow.

Table 3. Comparison of daily, monthly, and annual streamflow and its two components, surface runoff and baseflow, during the calibration period 1997-2002.

\begin{tabular}{cccccccccc}
\hline \multirow{2}{*}{ Flow } & Time & \multicolumn{3}{c}{ Mean (cm/day) } & \multicolumn{3}{c}{ Standard Deviation (cm/day) } & \multicolumn{2}{c}{ NSE } \\
\cline { 3 - 10 } & Period & USGS & SWAT & VSLF & USGS & SWAT & VSLF & SWAT & VSLF \\
\hline \multirow{2}{*}{ Surface } & Annual & 34.98 & 23.83 & 33.22 & 20.11 & 5.77 & 13.15 & 0.48 & 0.85 \\
runoff & Monthly & 2.32 & 1.99 & 2.48 & 3.98 & 2.18 & 2.75 & 0.65 & 0.68 \\
& Daily & 0.07 & 0.07 & 0.08 & 0.59 & 0.31 & 0.35 & 0.58 & 0.54 \\
\hline \multirow{3}{*}{ Baseflow } & Annual & 25.84 & 20.25 & 25.76 & 9.69 & 3.09 & 7.07 & -1.95 & 0.64 \\
& Monthly & 1.84 & 1.68 & 2.06 & 1.79 & 1.16 & 1.98 & 0.61 & 0.75 \\
& Daily & 0.06 & 0.06 & 0.07 & 0.07 & 0.06 & 0.07 & 0.37 & 0.55 \\
\hline \multirow{5}{*}{ Streamflow } & Annual & 60.82 & 44.09 & 58.98 & 28.78 & 8.23 & 20.07 & 0.40 & 0.86 \\
& Monthly & 4.15 & 3.67 & 4.54 & 5.20 & 3.11 & 4.43 & 0.68 & 0.74 \\
& Daily & 0.13 & 0.12 & 0.15 & 0.62 & 0.34 & 0.38 & 0.57 & 0.54 \\
\hline
\end{tabular}


The calibrated models were then used to predict the surface runoff, baseflow, and streamflow for the validation period 2003-2008, which were then compared to the observed streamflow and the derived baseflow and runoff at the Reaville Gage Station in the period (Table 4).

Table 4. Comparison of daily, monthly, and annual streamflow and its two components, surface runoff and baseflow, during the validation period 2003-2008.

\begin{tabular}{ccccccccccc}
\hline \multirow{2}{*}{ Flow } & Time & \multicolumn{3}{c}{ Mean (cm/day) } & \multicolumn{3}{c}{ Standard Deviation (cm/day) } & \multicolumn{2}{c}{ NSE } \\
\cline { 3 - 10 } & Period & USGS & SWAT & VSLF & USGS & SWAT & VSLF & SWAT & VSLF \\
\hline \multirow{2}{*}{ Surface } & Annual & 35.28 & 32.63 & 41.29 & 8.28 & 3.52 & 6.60 & 0.52 & 0.38 \\
runoff & Monthly & 3.04 & 2.73 & 3.50 & 3.26 & 2.50 & 3.33 & 0.63 & 0.81 \\
& Daily & 0.10 & 0.09 & 0.12 & 0.44 & 0.34 & 0.46 & 0.33 & 0.30 \\
\hline \multirow{3}{*}{ Baseflow } & Annual & 28.42 & 30.30 & 32.47 & 6.62 & 4.61 & 3.24 & 0.72 & 0.14 \\
& Monthly & 2.49 & 2.63 & 2.73 & 1.87 & 1.49 & 2.23 & 0.71 & 0.59 \\
& Daily & 0.08 & 0.09 & 0.09 & 0.09 & 0.08 & 0.09 & 0.50 & 0.55 \\
\hline \multirow{3}{*}{ Streamflow } & Annual & 63.71 & 62.93 & 73.76 & 13.96 & 7.90 & 9.44 & 0.75 & 0.35 \\
& Monthly & 5.53 & 5.35 & 6.23 & 4.85 & 3.60 & 4.98 & 0.68 & 0.79 \\
& Daily & 0.18 & 0.18 & 0.21 & 0.48 & 0.37 & 0.50 & 0.37 & 0.38 \\
\hline
\end{tabular}

SWAT tended to underestimate and VSLF overestimate surface runoff and streamflow, while both were consistent in simulating baseflow showing by the means of simulated and observed flows. Both SWAT and VSLF tended to underestimate the variability of the flows showing lower standard deviations, but the variability captured by VSLF is closer to the observed variability than SWAT. Such findings were further confirmed by the hydrographs of the simulated and observed streamflow at the Reaville Gage Station (Figure 5).

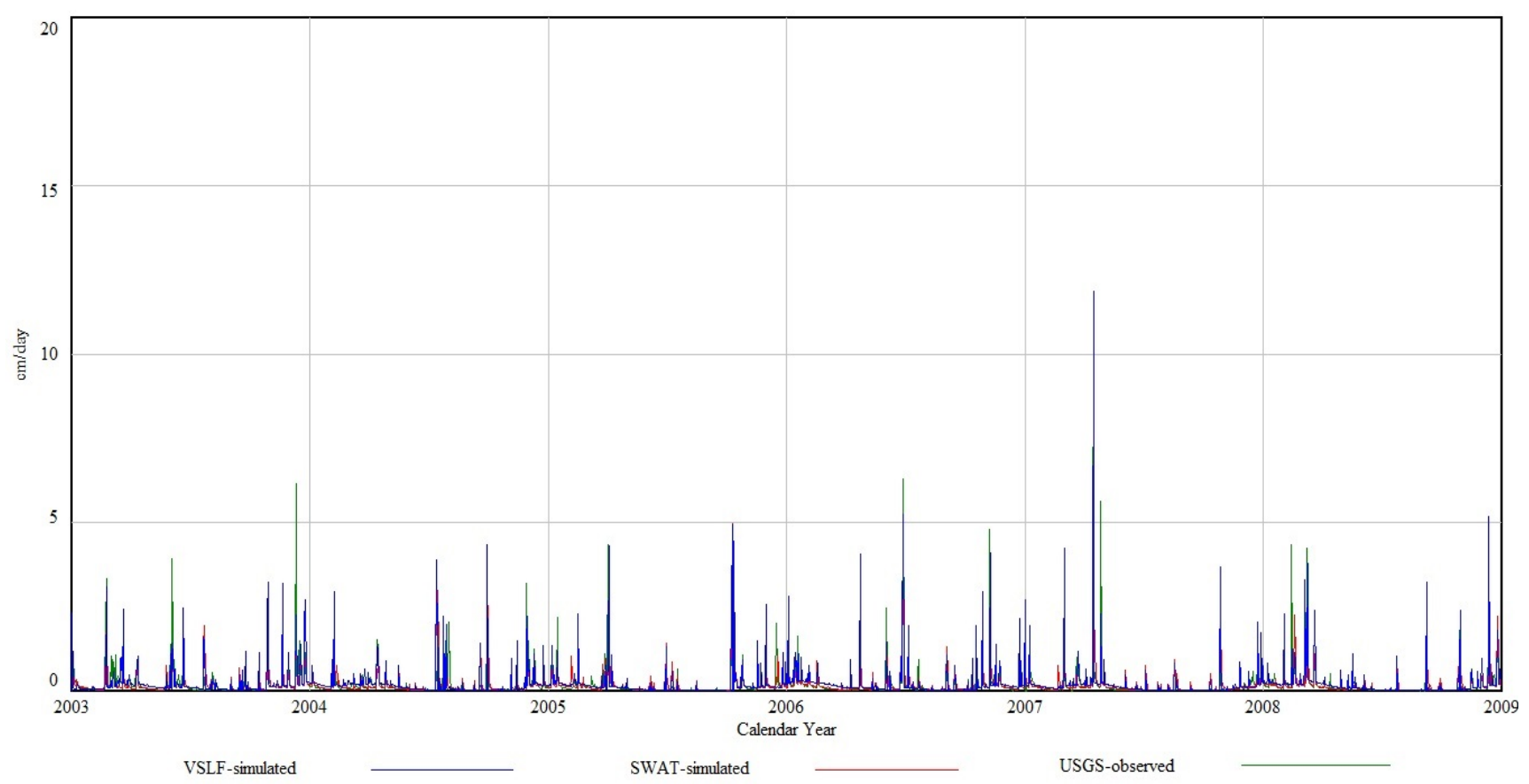

Figure 5. Comparison of VSLF- and SWAT-simulated and USGS-observed streamflow at the Reaville Gage Station in the Neshanic River Watershed. 
The NSEs for the SWAT model during the validation period were $0.33,0.50$, and 0.37 for the daily surface runoff, baseflow, and streamflow; $0.63,0.71$, and 0.68 for the monthly surface runoff, baseflow, and streamflow; and 0.52, 0.72, and 0.75 for the annual surface runoff, baseflow, and streamflow during the calibration period, respectively. The NSEs for the VSLF model were 0.30, 0.55, and 0.38 for the daily surface runoff, baseflow, and streamflow; $0.81,0.59$, and 0.79 for the monthly surface runoff, baseflow, and streamflow; and $0.38,0.14$, and 0.35 for the annual surface runoff, baseflow, and streamflow during the validation period, respectively. Following the same performance ratings provided by [56], these NSE values for the monthly streamflow indicated that the validation is very good for the VSLF model and good for the SWAT model. The differences in NSEs for the two models between the calibration and validation periods might be partially due to the changes in land uses in the watershed during the validation period while the model was still based on the land use conditions in 2002. Those measurements indicated both SWAT and VSLF achieved comparable predictions in surface runoff, baseflow, and streamflow in the watershed.

\section{Conclusions}

Natural hydrological processes coupled with historical land use management practices form various hydrological hotspots and/or CSAs in watersheds. The VSA hydrology and TI consistent with such a hydrological concept have been used to characterize hydrological sensitivity, and identify and delineate HSAs and/or CSAs in watersheds. Such characterization allows resource management practitioners to take spatially discrete land use management actions to protect water quality and aquatic ecosystem health in watersheds. It is essential to validate such a useful tool so that a suite of effective watershed management strategies can be built upon and implemented to improve management efficiency.

The study shows there are some practical difficulties to virtually validate the TI spatial pattern through field soil moisture sampling due to the significant impacts of micro-variations in soil, topography, and vegetation. The statistical analyses indicate a positive and high correlation between the TDR soil moisture measurements and the TI values, as shown on the binned graphs. Such correlation indicates that TI reasonably approximates the soil moisture condition, and therefore reasonably represents variability in runoff-generating potentials in landscapes. The lower correlation cases, as shown in Figures 3b and 4b, occurred because of the dry ground conditions on 1 December 2009 and the poor selection of the sampling locations in the Cold Brook Preserve. Future field studies on TI validation should select sampling locations with diverse TI values and should be conducted in wet seasons. For example, instead of randomly selecting sampling points on site, future validation studies might pre-select those sampling locations to cover a wider TI range and have a significant amount of locations in very different parts of a watershed to have a fuller representation of a watershed.

VSLF watershed modeling results indicate that incorporating TI into a lumped watershed model simulates the watershed hydrology reasonably well, as indicated by the goodness-of-fit in predicting surface runoff, baseflow, and streamflow in the Neshanic River Watershed during both the calibration and validation period. Such goodness-of-fit is comparable to the SWAT model in the same watershed using the same datasets. The simulation precision in watershed modeling is often achieved by dividing a watershed into smaller but different units with each unit representing a unique hydrological condition. Despite the similar modeling performance, the complexity of representing the watershed 
was quite different between the two models. In SWAT modeling, the same watershed was divided into 21 subbasins and 523 HRUs. Comparatively, VSLF used a much simpler watershed representation, i.e., intersections between land uses and 10 saturation class-based TI values. The watershed modeling incorporating TI can significantly improve the modeling efficiency.

In conclusion, TI is a good indicator for hydrological sensitivity in a watershed, provides a meaningful understanding on hydrological connections in a watershed and watershed hydrology, and therefore is a useful tool for watershed and water resource management. Such validation gives resource management practitioners the confidence to use TI and implement TI-based, spatially discrete land use management actions in watershed and water resource management practices.

\section{Acknowledgments}

The funding support for the project was partially provided by the US Environmental Protection Agency's National Center for Environmental Research through the Collaborative Science and Technology Network for Sustainability Program (Grant Number RD-83336301-0) and the US Department of Agriculture's National Institute of Food and Agriculture through the Agriculture and Food Research Initiative (Grant Number 2012-67019-19348).

\section{Conflicts of Interest}

The founding sponsors had no role in the design of the study; in the collection, analyses, or interpretation of data; in the writing of the manuscript, and in the decision to publish the results.

\section{References}

1. Steenhuis, T.S.; Muck, R.E. Preferred movement of nonadsorbed chemicals on wet, shallow, sloping, soils. J. Environ. Qual. 1988, 17, 376-384.

2. Merwin, I.A.; Stiles, W.C.; Vanes, H.M. Orchard groundcover management impacts on soil physical-properties. J. Am. Soc. Hort. Sci. 1994, 119, 216-222.

3. Walter, M.T.; Mehta, V.K.; Marrone, A.M.; Boll, J.; Gérard-Merchant, P.; Steenhuis, T.S.; Walter, M.F. A simple estimation of the prevalence of Hortonian flow in New York City's watersheds. J. Hydrol. Eng. 2003, 8, 214-218.

4. Hewlett, J.D.; Hibbert, A.R. Factors affecting the response of small watersheds to precipitation in humid areas. In Forest Hydrology; Sopper, W.E., Lull, H.W., Eds.; Pergamon Press: Oxford, UK, 1967; pp. 275-290.

5. Dunne, T.; Leopold, L.B. Water in Environmental Planning; W.H. Freeman and Company: New York, NY, USA, 1978; p. 818.

6. Hewlett, J.D. Principles of Forest Hydrology; University of Georgia Press: Athens, GA, USA, 1982; p. 183.

7. Gburek, W.D.; Sharpley, A.N. Hydrologic controls on phosphorus loss from upland agricultural watersheds. J. Environ. Qual. 1998, 27, 267-277. 
8. Walter, M.T.; Walter, M.F.; Brooks, E.S.; Steenhuis, T.S.; Boll, J.; Weiler, K. Hydrologically sensitive areas: Variable source area hydrology implications for water quality risk assessment. J. Soil Water Conserv. 2000, 55, 277-284.

9. Walter, M.T.; Brooks, E.S.; Walter, M.F.; Steenhuis, T.S.; Scott, C.A.; Boll, J. Evaluation of soluble phosphorus loading from manure-applied fields under various spreading strategies. J. Soil Water Conserv. 2001, 56, 329-335.

10. Heathwaite, L.; Quinn, P.F.; Hewett, C. Modelling and managing critical source areas of diffuse pollution from agricultural land using flow connectivity simulation. J. Hydrol. 2005, 304, 446-461.

11. Agnew, L.J.; Walter, M.T.; Lembo, A.; Gérard-Marchant, P.; Steenhuis, T.S. Identifying hydrologically sensitive areas: Bridging science and application. J. Environ. Manag. 2006, 78, 64-76.

12. Qiu, Z. Identifying critical source areas in watersheds for conservation buffer planning and riparian restoration. Environ. Manag. 2009, 44, 968-980.

13. Qiu, Z.; Hall, C.; Drewes, D.; Messinger, G.; Prato, T.; Hale, K.; van Abs, D. Hydrologically sensitive areas, municipal land use controls and protection of healthy watersheds. J. Water Res. Plan. Manag. 2014, 140, doi:10.1061/(ASCE)WR.1943-5452.0000376

14. Beven, K.J.; Kirkby, M.J. A physically based, variable contributing area model of basin hydrology. Hydrol. Sci. Bull. 1979, 24, 43-69.

15. O'Loughlin, E.M. Prediction of surface saturation zones in natural catchments by topographic analysis. Water Resour. Res. 1986, 22, 794-804.

16. Moore, I.D.; Grayson, R.B.; Ladson, A.R. Digital terrain modelling: A review of hydrological, geomorphological, and biological applications. Hydrol. Proc. 1991, 5, 3-30.

17. Beven, K. TOPMODEL: A critique. Hydrol. Proc. 1997, 11, 1069-1085.

18. Gomez-Plaza, A.; Martinez-Mena, M.; Albaladejo, J.; Castillo, V.M. Factors regulating spatial distribution of soil water content in small semiarid catchments. J. Hydrol. 2001, 253, 211-226.

19. Wilson, D.J.; Western, A.W.; Grayson, R.B. A terrain and data-based method for generating the spatial distribution of soil moisture. Adv. Water Resour. 2005, 28, 43-54.

20. Hornberger, G.M.; Beve, K.J.; Csby, B.J.; Sappington, D.E. Shenandoah watershed study: Calibration of a topography-based, variable contributing area hydroloigical model to a small forested catchment. Water Resour. Res. 1985, 21, 1841-1850.

21. Wood, E.F.; Sivapalan, M.; Beven, K.J. Similarity and scale in catchment storm response. Rev. Geophys. 1990, 28, 1-18.

22. Gallart, F.; Latron, J.; Llorens, P.; Beven, K. Using internal catchment information to reduce the uncertainty of discharge and baseflow predictions. Adv. Water Resour. 2007, 30, 808-823.

23. Schneiderman, E.M.; Steenhuis, T.S.; Thongs, D.J.; Easton, Z.M.; Zion, M.S.; Neal, A.L.; Mendoza, G.F.; Walter, M.T. Incorporating variable source area hydrology into Curve Number based watershed loading functions. Hydrol. Proc. 2007, 21, 3410-3430.

24. Grayson, R.B.; Western, A.W. Towards areal estimation of soil water content from point measurements: Time and space stability of mean response. J. Hydrol. 1998, 207, 68-82.

25. Yeakley, J.A.; Swank, W.T.; Swift, L.W.; Hornberger, G.M.; Shugart, H.H. Soil moisture gradients and controls on a southern Appalachian hillslope from drought through recharge. Hydrol. Earth Syst. Sci. 1998, 2, 41-49. 
26. Grayson, R.B.; Blöschl, G.; Western, A.W.; McMahon, T.A. Advances in the use of observed spatial patterns of catchment hydrological response. Adv. Water Resour. 2002, 25, 1313-1334.

27. Moore, I.D.; Thompson, J.C. Are water table variations in a shallow forest soil consistent with the TOPMODEL concept? Water Resour. Res. 1996, 32, 663-669.

28. Siebert, J.; Bishop, K.H.; Nyberg, L. A test of TOPMODEL's ability to predict spatially distributed groundwater levels. Hydrol. Proc. 1997, 11, 1131-1144.

29. Rodhe, A.; Seibert, J. Wetland occurrence in relation to topography: A test of topographic indices as moisture indicators. Agric. Forest Meteorol. 1999, 98, 325-340.

30. Merot, P.; Squividant, H.; Aurousseau, P.; Hefting, M.; Burt, T.; Maitre, V.; Kruk, M.; Butturini, A.; Thenail, C.; Viaud, V. Testing a climato-topographic index for predicting wetlands distribution along an European climate gradient. Ecol. Model. 2003, 163, 51-71.

31. Nyberg, L. Spatial variability of soil water content in the covered catchment at Gardsjon, Sweden. Hydrol. Proc. 1996, 10, 89-103.

32. Chaplot, V.; Walter, C. Subsurface topography to enhance the prediction of the spatial distribution of soil wetness. Hydrol. Proc. 2003, 17, 2567-2580.

33. Bardossy, A.; Lehmann, W. Spatial distribution of soil moisture in a small catchment. Part 1: Geostatistical analysis. J. Hydrol. 1998, 206, 1-15.

34. Sulebak, J.R.; Tallaksen, L.M.; Erichsen, B. Estimation of areal soil moisture by use of terrain data. Geogr. Ann. 2000, 82, 89-105.

35. Pellenq, J.; Kalmab, J.; Bouleta, G.; Saulnierc, G.M.; Wooldridgeb, S.; Kerra, Y.; Chehbouni, A. A disaggregation scheme for soil moisture based on topography and soil depth. J. Hydrol. 2003, 276, 112-127

36. Walter, M.T.; Steenhuis, T.S.; Mehta, V.K.; Thongs, D.; Zion, M.; Schneiderman, E. A refined conceptualization of TOPMODEL for shallow-subsurface flows. Hydrol. Proc. 2002, 16, 2041-2046.

37. Lyon, S.W.; Gérard-Marcant, P.; Walter, M.T.; Steenhuis, T.S. Using a topographic index to distribute variable source area runoff predicted with the SCS-curve number equation. Hydrol. Proc. 2004, 18, 2757-2771.

38. Frankenberger, J.R.; Brooks, E.S.; Walter, M.T.; Walter, M.F.; Steenhuis, T.S. A GIS-based variable source area hydrology model. Hydrol. Proc. 1999, 13, 805-822.

39. De Alwis, D.A.; Easton, Z.M.; Dahlke, H.E.; Philpot, W.D.; Steenhuis, T.S. Unsupervised classification of saturated areas using a time series of remotely sensed images. Hydrol. Earth Syst. Sci. 2007, 11, 1609-1620.

40. Haith, D.A.; Shoemaker, L.L. Generalized Watershed Loading Functions for stream flow nutrients. Water Resour. Bull. 1987, 23, 471-478.

41. Schneiderman, E.M.; Pierson, D.C.; Lounsbury, D.G.; Zion, M.S. Modeling the hydrochemistry of the Cannonsville Watershed with Generalized Watershed Loading Functions (GWLF). J. Amer. Water Resour. Assoc. 2002, 38, 1323-1347.

42. New Jersey Department of Environmental Protection (NJDEP). 2008 New Jersey Integrated Water Quality Monitoring and Assessment Report. Available online: http://www.nj.gov/dep/wms/bwqsa/ 2008_final_IR_complete.pdf (accessed on 1 October 2015).

43. Qiu, Z. Comparative assessment of stormwater and nonpoint source pollution bet management practices in suburban watershed management. Water 2013, 5, 280-291. 
44. Freeze, R.A.; Cherry, J.A. Groundwater; Prentice-Hall Inc.: Englewood Cliffs, NJ, USA, 1979; p. 604.

45. Tarboton, D.G. Terrain Analysis Using Digital Elevation Models (TauDEM). Available online: http://hydrology.usu.edu/taudem/taudem5/index.html (accessed on 14 August 2015).

46. Spectrum Technologies, Inc. Fieldscout TDR 300 Soil Moisture Meter Product Manual; Spectrum Technologies Inc.: Plainfield, IL, USA, 2009; p. 20.

47. New Jersey Department of Environmental Protection (NJDEP). NJDEP GPS Data Collection Standards for GIS Data Development. Available online: http:/www.nj.gov/dep/gis/ GPSStandards_2011.pdf (accessed on 1 October 2015).

48. New Jersey Department of Environmental Protection (NJDEP). 2002 Land Use/Land Cover by Watershed Management Area. Available online: http://www.state.nj.us/dep/gis/lulc02cshp.html (accessed on 1 October 2015).

49. Nash, J.E.; Sutcliffe, J.V. River flow forecasting through conceptual models, part 1-A discussion of principles. J. Hydrol. 1970, 10, 282-290.

50. Arnold, J.G.; Allen, P.M.; Muttiah, R.; Bernhardt, G. Automated base flow separation and recession analysis techniques. Ground Water 1995, 33, 1010-1018.

51. Arnold, J.G.; Srinivason, R.; Muttiah, R.R.; Williams, J.R. Large area hydrologic modeling and assessment part 1: Model development. J. Amer. Water Resour. Assoc. 1998, 34, 73-89.

52. Gassman, P.W.; Reyes, M.R.; Green, C.H.; Arnold, J.G. The soil and water assessment tool: Historical development, applications, and future research directions. Trans. Amer. Soc. Agric. Eng. 2007, 50, 1211-1250.

53. Neitsch, S.L.; Arnold, J.G.; Kiniry, J.R.; Williams, J.R.; King, K.W. Soil and Water Assessment Tool Theoretical Documentation, Version 2005; USDA-ARS Grassland, Soil and Water Research Laboratory: Temple, TX, USA, 2005.

54. Winchell, M.; Srinivasan, R.; di Luzio, M.; Arnold, J.G. ArcSWAT 2.3 Interface for SWAT2005-User's Guide; USDA-ARS Grassland, Soil and Water Research Laboratory: Temple, TX, USA, 2009.

55. Qiu, Z.; Wang, L. Hydrological and water quality assessment in a suburban watershed with mixed land uses using the SWAT model. J. Hydrol. Eng. 2014, 19, 816-827.

56. Moriasi D.N.; Arnold, J.G.; van Liew, M.W.; Binger, R.L.; Harmel, R.D.; Veith, V. Model evaluation guidelines for systematic quantification of accuracy in watershed simulations. Trans ASABE 2007, 50, 885-900.

(C) 2015 by the authors; licensee MDPI, Basel, Switzerland. This article is an open access article distributed under the terms and conditions of the Creative Commons Attribution license (http://creativecommons.org/licenses/by/4.0/). 